\title{
Brief Analysis on the Artistic Style of Beardsley Illustrations
}

\author{
Miao Zhang \\ School of Art and Design \\ Huanghe Science and Technology College \\ Zhengzhou, China, 450000 \\ e-mail: 41597449@qq.com
}

\begin{abstract}
The crucial factor that the illustration art of Beardsley can obtain remarkable achievements is the unique characteristics of the art itself. The era of Beardsley is a complex era with contradictions, and "New and old" constantly collide. In the field of illustration art, Beardsley continuously uses new forms and new means to open up and renovate the visual aesthetic world of people.
\end{abstract}

Keywords-Beardsley; illustration; artistic style

\section{INTRODUCTION}

Aubrey Beardsley (1872-1898) is one of the most famous artists of the British even the world in the end of 19th century and he dies at the age of 26 years old. In the process of Beardsley's short life, his illustration art career is shorter. However, his artistic achievement impact can be described as "There isn't an artist who draws black and white paintings can acquire a more general reputation than him; also there isn't an artist who widely influences modern art like him".

\section{THE ILLUSTRATION CAREER OF BEARDSLEY}

The illustration art career of Beardsley begins in 1891. In that year, his artistic talents and styles suffer the "belittlement and desolation" from William Morris, but get the recognition and great encouragement from Burne-Jones: "...these paintings are full of thoughts, poetry and imagination and nature gives you all qualities to become a great painter". ${ }^{1}$ The words "I seldom or never advise people to take art as a career, but for you, I can only give such advice" 2 that Burne-Jones says to Beardsley exactly encourage him greatly and make him put his weak, sick body and divine, excellent artistic talent and creative passion into the creation activity of illustration art.

In 1892, influenced by the artistic style of Japanese prints and aestheticism artist whistler, Beardsley gradually forms his own unique "black and white painting", "the mysterious feelings expressed by the effect of black and white picture and succinct powerful representation lay foundation for his

\footnotetext{
${ }^{1}$ Jin Lide. Beardsley Illustration Art [M]. Nanning: Lijiang Publishing House, 1988:5.

${ }^{2}$ Li Jianqun. Story of British Art[M]. Beijing: People's Fine Arts Publishing House, 2000:163.
}

later artistic style". This year is important stage when Beardsley illustration artistic style forms and sets the tone. From his works Raphael Sanzio "Fig. 1" we can see his artistic style in this period has a distinct characteristic of "Japanese style",

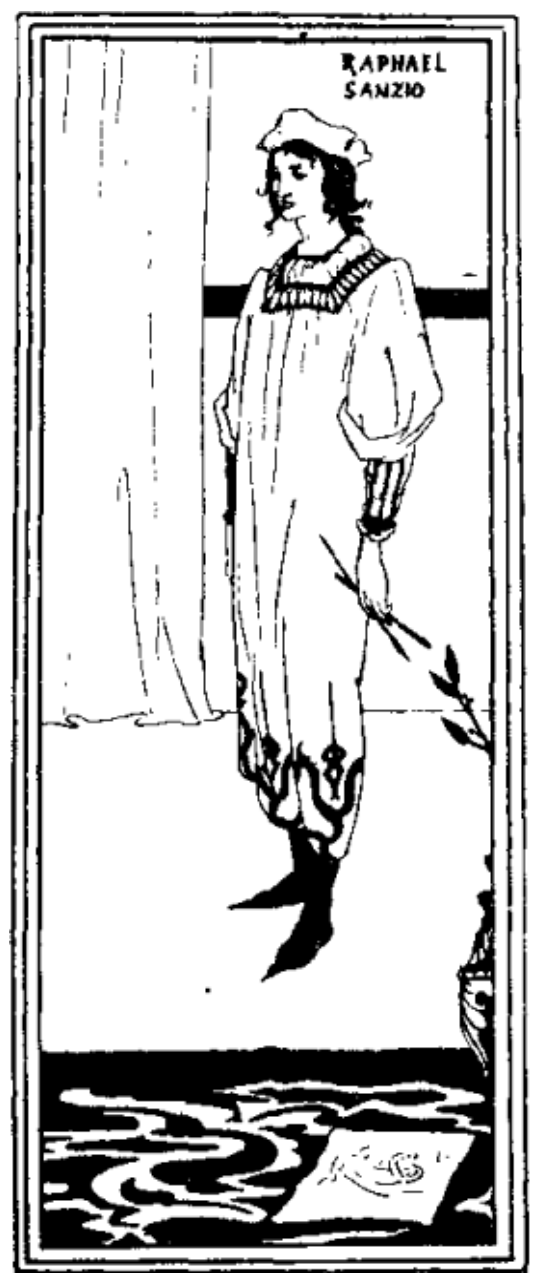

Fig. 1. Raphael Sanzio

\footnotetext{
${ }^{3}$ Ma Fenglin. Beardsley's Art World[M]. Changsha: Hunan Fine Arts Publishing House, 1988:30.
} 
In 1893, Beardsley makes illustrations for the medieval knight story The Death of King Arthur. He uses the skilled wood carving line technique and sharp contrast of black and white color in the illustration creation of this book, further consolidating and establishing his unique artistic style. Through the analysis of illustration Tristram Drinks the Wine of Love "Fig. 2", it is easy to know the features of Beardsley's illustration art: black and white contrast, beautiful lines and Japanese prints style.

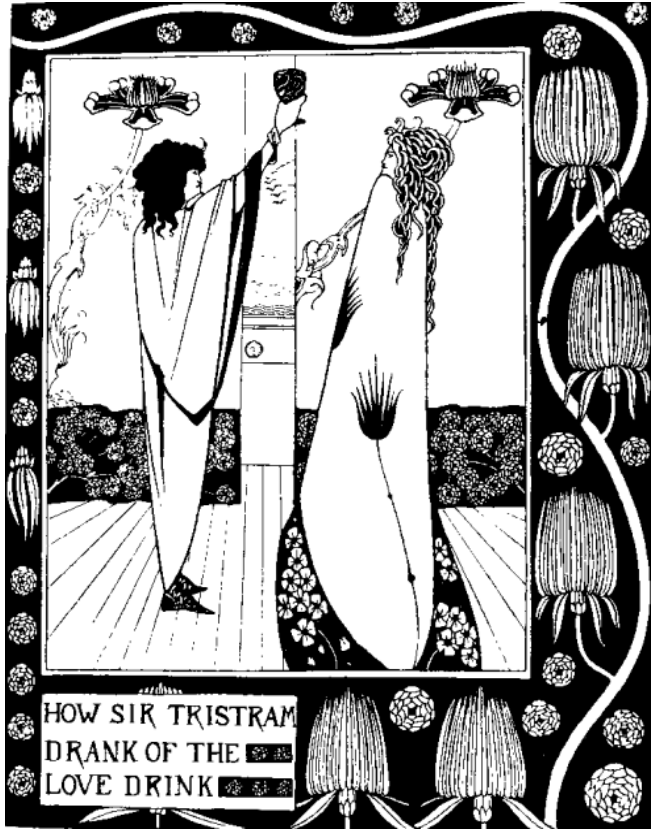

Fig. 2. Tristram Drinks the Wine of Love

During the year of 1894 to 1895 , Beardsley is the art editor and illustration art designer of the magazine Yellow Book. On one hand, he bears the huge pressure of public opinion. On the other hand, he continues to work on illustration artistic creation. His use of elegant and smooth lines is more skillful. Except for insisting characteristic of pure and strong black and white creation, Beardsley as well "tries the training of tints and shades" to make the picture generate "rich color gradation". At this time, Beardsley has become one of the most famous artists in Britain.

In 1896, after being influenced by the "Wilde Event", Beardsley gradually moves towards the new creation stage. With the constant aggravated illness, the life of Beardsley's artistic creation becomes more robust and enters the golden age of his creation. At the moment, most of his illustration artistic works are published on the magazine Savoy. Except for the beauty of lines and decoration on visual perception, his illustrations include the obscure, symbolic, imaginative, critical and ironic contents in connotation. From 1897 to 1898, Beardsley uses proficient artistic creation skills and rich artistic imagination to deliver his cognition and

\footnotetext{
${ }^{4}$ Zhang Wang. Beardsley's Decorative Picture [M]. Shenyang: Liaoning

Fine Arts Publishing House, 1981:7

${ }^{5}$ Ma Fenglin. Beardsley's Art World[M]. Changsha: Hunan Fine Arts Publishing House, 1988:44
}

understanding of social evils, the hypocrisy of human nature, fear and hope in the inner world, love and sexual attitudes to the public through the creation and publication of illustrations.

On March 16th, 1898, Beardsley passes away. But the influence he has on illustration art even the realm of art is continuous till now.

\section{The ARTistic STYLE OF BEARDSLEY's ILLUSTRATIONS}

The crucial factors that Beardsley's illustration art can obtain remarkable achievements are the unique characteristics of the art itself:

1) Innovative art form. It mainly refers to the external visual esthetics of Beardsley's illustration artistic workperfect combination of elegant and fluent line and opposite black and white block surface. Therefore, we say Beardsley's illustration art has distinctive style of aestheticism. Beardsley "pursues aestheticism and is a representative artist with the character of 'art for art's sake"". 6

2) Contradictory and complex artistic content. It mainly reflects that Beardsley uses the ways such as "symbol" $\uparrow$, metaphor and marks to indirectly express his experiences for the outside world and the inner world. Thus it gives various and blurry cognition and feelings for viewers. So his art has the style of symbolism.

3) "Freehand style" with the combination of "fantasy and imagination" " 8 -prominent features of Beardsley's artistic thought. Beardsley has good artistic talent when he is very young. He involves many fields such as drawing, music, literature (novel, poetry) and drama, etc. What the most important is that Beardsley keeps reading a good deal of literature and history books throughout his life. Thus he opens infinite vast and miraculous "world" of imagination and fantasy.

\section{A. Elegant and Fluent Style of Aestheticism}

Aestheticism derives from the anti-traditional art concept of "art for art's sake" put forward by Gautier. Its core concept thinks: art should pursue forms and senses, and oppose contents and thoughts. The creation activity of Beardsley's illustration art is in the process of aestheticism movement, and the multiple influences in artistic creation concepts and forms from artists such as Rossetti, BurneJones, Whistler, Baudelaire and Wilde who belongs to the artistic schools of pre-Raphaelite, symbolism, aestheticism and decadence respectively. Therefore, Beardsley's illustration art has distinct aestheticism art style from beginning to end.

\footnotetext{
${ }^{6}$ Li Xingyuan. The Outline of Western Art History [M]. Changsha: Hunan Fine Arts Publishing House, 2002: 141

${ }^{7}$ Li Jianqun. Story of British Art[M]. Beijing: People's Fine Arts Publishing House, 2000:76

${ }^{8}$ Li Jianqun. Story of British Art[M]. Beijing: People's Fine Arts Publishing House, 2000:77
} 
The aestheticism styles of Beardsley's art mainly reflect in two aspects:

1) Smooth, elegant lines and the dense, naturalistic decorative features presented from this. All kinds of vines, flowers and other plants in the nature are widely expressed in the Beardsley's illustration artistic art in the form of lines. Analyzing from the angle of visual arts, itself has the characteristics of pure decoration. For example, the illustration artistic works Sir Rouse Lott and Witch Heloise 1983 "Fig. 3" is exactly the representation of this style.

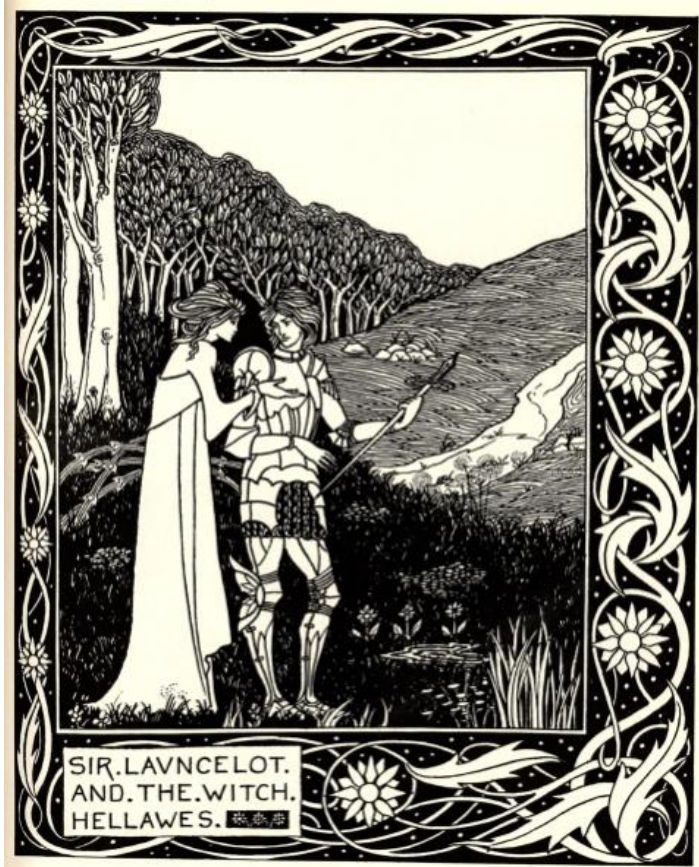

Fig. 3. Sir Rouse Lott and Witch Heloise

2) Concise, opposite black and white block and plane. The "colors" that Beardsley uses in his illustration art are only black and white. Both of them present in his artistic works in the regular or flexible free forms of block and plane. Strong black and white contrasts and concise forms of block and plane all show its ${ }^{9}$ characteristics of aestheticism style. Even though Beardsley also engages in colorful illustrations artistic creation, compared with black and white painting, its artistic achievement is a little inferior, as shown in "Fig. 4".

As shown in "Fig. 5" Oriental Dancer, it belongs to this characteristic, perfectly combining concise, opposite black and white color lump with smooth, soft lines to make viewers generate the feelings of dancing with the wind.

Except for being reflected in the creative spirit presented from this style characteristic and tactfully using lines and black and white color lump to build perfect visual image, Beardsley's illustration artistic achievements rest on the contradictoriness, symbolism and metaphor of its artistic connotation.

\section{B. Ironic and Metaphorical Symbolism Style}

The era of Beardsley is a complex era with contradictions, and "New and old" constantly collide. In the field of illustration art, Beardsley continuously uses new forms and new means to open up and renovate the visual aesthetic world of people. In the aspect of the content of art, Beardsley's ideas collide with the temporal mainstreamtraditional values. On one hand, his spirit of daring to challenge the traditional art concepts and social thoughts helps him to win praise; on the other hand, it plants hidden danger for him to suffer great setbacks.

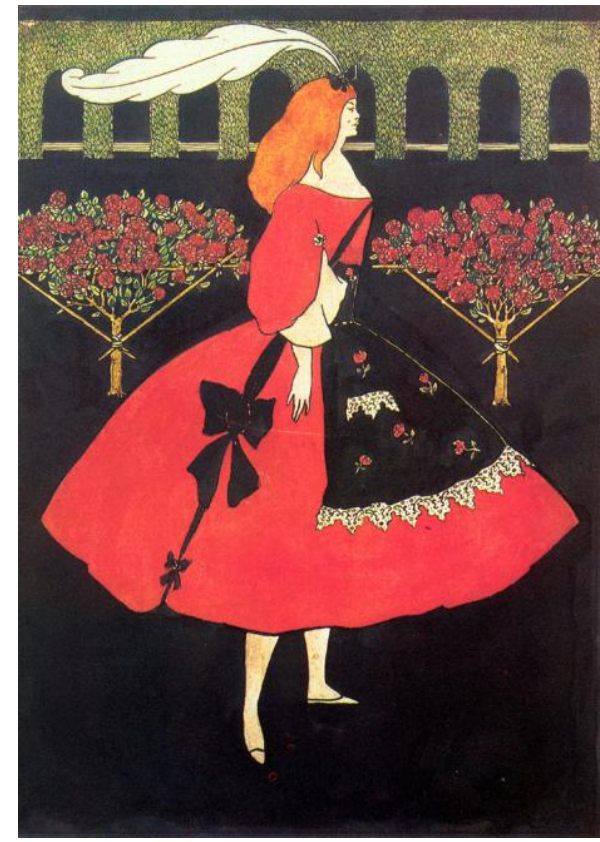

Fig. 4. Cinderella's Slipper age unknown

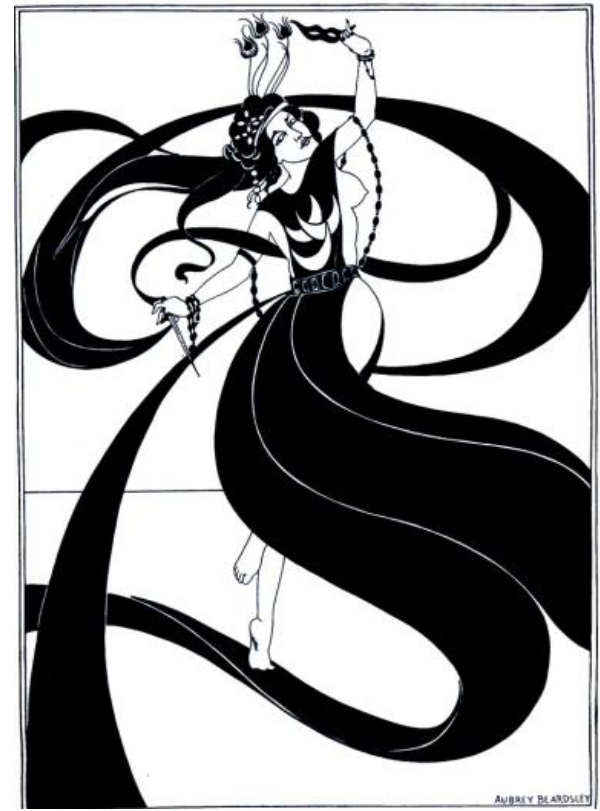

Fig. 5. Picture 5 Oriental Dancer 
There are many symbolic contents involved in Beardsley's illustration art, such as sexual attitudes, the social roles of men and women, inner thoughts and feelings, attitudes toward life, social ethical ideas, evaluation of new art and new culture, etc. It is widely think that his artistic works have obvious and dense meaning of eroticism and it reflects in many of his works. For example, Lacey Strata Hides the Pudendum 1896 "Fig. 6" and Herodias "Fig. 7" have the application of obvious "sex" situation and sex symbol. The "candle" 10 in Herodias is symbolic sign of male.

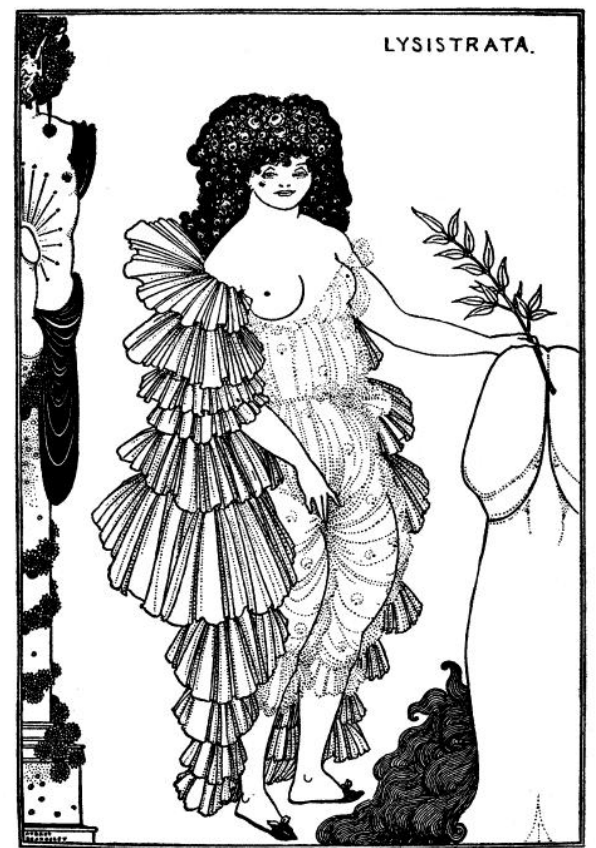

Fig. 6. Lacey Strata Hides the Pudendum 1896

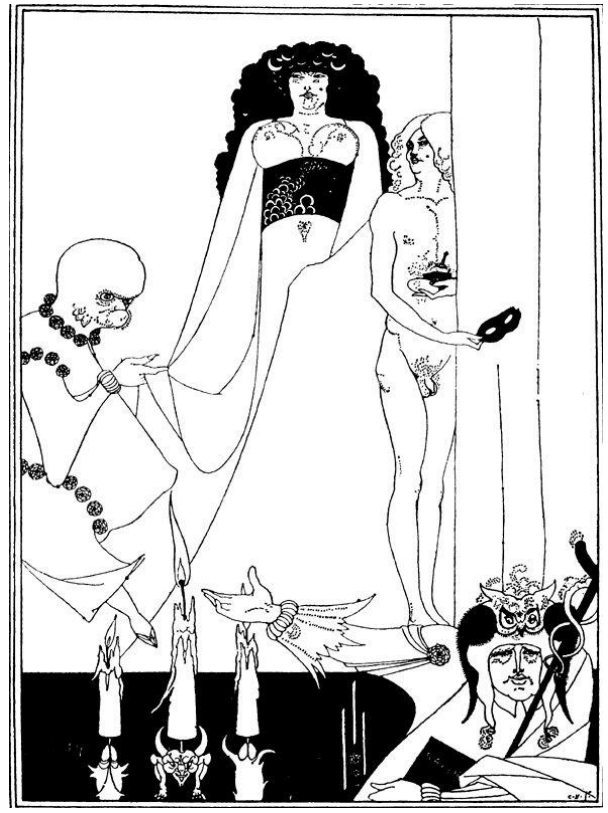

Fig. 7. Herodias

\footnotetext{
${ }^{10}$ Ma Fenglin. Beardsley's Art World[M]. Changsha: Hunan Fine Arts Publishing House, 1988:43
}

Beardsley uses the art form of contradictions to criticize the "pseudo moral" and the suppression for female freedom and normal love in Victorian era. Queen Victoria's view is that "If a woman is not a chippie, she must be a vestal virgin. So at that time, the normal lust of British people is greatly distorted." "From Beardsley's correspondences, we can also see his maintenance and sympathy for woman's rights at that time. When George Sand, the pioneer of British feminist writer in 19th century, suffers from the social unfair treatment, Beardsley says "Recently, I read some early period works of George Sand such as The Devil's Pool, Consuelo, etc. What an abominable behavior that she is robbed by the multitudes!" 12

Furthermore, Beardsley continuously criticizes the social bad phenomenon in his works. The ugly realities such as "hypocrite", "money beliefs", "false knowledge" are expressed in his artistic works in indirect forms such as symbolization and metaphor, etc. Illustrations such as Susanna and Beggars, Wall Bony Worships His Jewel all reveal Beardsley's sarcasm and criticism for the cruel society and distorted belief at that time.

The symbolism and metaphor of Beardsley's works bring obscure and polysemantic interpreted results for viewers. However, it is exactly the use of symbolism style that makes Beardsley's works have more mysterious colors. Meanwhile, it is also an important part of his artistic charm.

\section{The Freehand Style of Combination of Fantasy and Imagination}

Beardsley's artistic works fully reflect his proficient understanding and application for the artistic thought of imagination and fantasy. In the final analysis, such amazing artistic thinking ability possessed by Beardsley derives from the fact that he sedulously absorbs the essence of all kinds of arts such as "novels, myths, poems, plays, biographies, music and painting". ${ }^{13}$ All of these provide the source of imagination and inspiration for Beardsley's artistic creation.

The knowledge areas that Beardsley involves are very vast. In his last correspondence, we can observe this fact. For example, he becomes interested in Greek mythology through understanding Pan. "Pan has man's torso and head, legs, horns and ears of goat." ${ }^{14}$ This kind of image frequently appears in Beardsley's illustration artistic works. From this, we can also realize the significance of fairy story for Beardsley's artistic creation. He forms new artistic images through artistic imagination and build.

Many weird character images and animal images appear in "black and white space" in Soren Truth Antology "Fig. 8" and reflect the sarcasm and criticism for the deformed society. Beardsley uses imagination and fantasy to create

\footnotetext{
${ }^{11}$ Ma Fenglin. Beardsley's Art World[M]. Changsha: Hunan Fine Arts Publishing House, 1988:39

12 British Beardsley. The Last Correspondence[M].Zhang

Hengyi.Beijing:Xinxing Press, 2009:60

${ }^{13}$ British Beardsley. The Last Correspondence[M].Zhang

Hengyi.Beijing:Xinxing Press, 2009:249

${ }^{14}$ British Beardsley. The Last Correspondence[M].Zhang Hengyi.Beijing:Xinxing Press, 2009:5
} 
colorful artistic world. In this world, except for the contents which make the heart uncomfortable such as doubt, fear, sneer, desire and depression, there are many idyllic "freehand" works which can make our uneasy state of mind move towards peace. The illustration works in books such as The Death of King Arthur, Salome have this kind of freehand style. Looking from the surface, "Fig. 9" shows the artistic conception that spring is in the air. But its theme is named The Withered Spring. This contrast causes deeper touches and thinking for us.

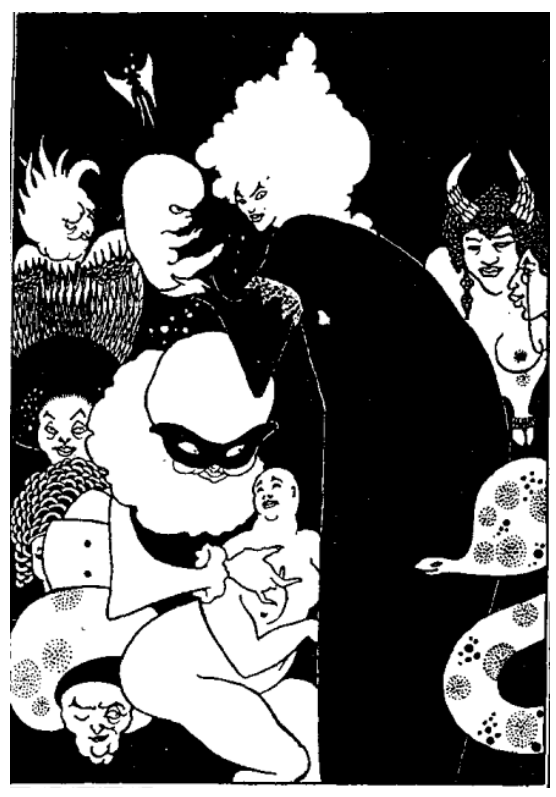

Fig. 8. Soren Truth Antology illustration 1895

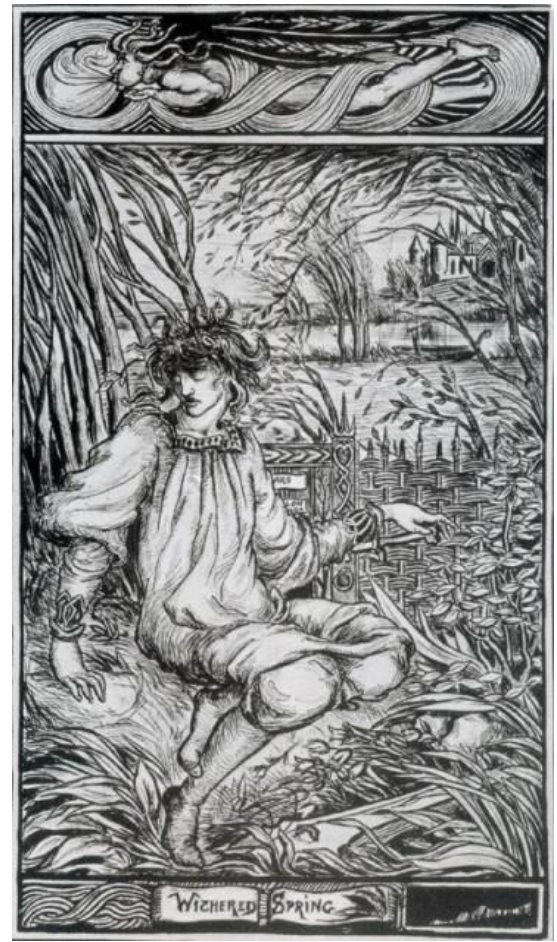

Fig. 9. The Withered Spring
There are two major reasons for the form of Beardsley's freehand style: on one hand, the general trend of western painting development has separated itself from the constraint of classical realism and turns from objective entity to subject; on the other hand, because Beardsley doesn't accept special artistic training and his essentials of basic training for realism is weak. Beardsley's only artistic plight is: to choose what kind of form to comprehensively display the inner world of self. He has found the solution discussed in the above article that is three main aspects of the fluent lines, black and white blocks, imagination and fantasy.

Beardsley is an outstanding artist "at the end of the world". Even though he has "flaws" in the aspects of artistic conception expression and the inner world experience, he has made indelible contributions for the field of plane designs. Especially it has positive significance of advance and reference for promoting the development of modern art, modern design, as well as the birth of plane designs and the development of postmodern art design and digital media art.

\section{REFERENCES}

[1] Jin Lide. Beardsley Illustration Art [M]. Nanning: Lijiang Publishing House, 1988

[2] British Roger Fley. Vision and Design [M].Translated by Yi Ying Nanjing: Jiangsu Education Publishing House, 2005

[3] Li Sida. Introduction to Digital Media Art [M]. Bejing: Tsinghua University Press, 2006

[4] Zhang Wang. Beardsley's Decorative Picture [M]. Shenyang: Liaoning Fine Arts Publishing House, 1981

[5] Li Jianqun. Story of British Art [M]. Beijing: People's Fine Arts Publishing House, 2000

[6] Ma Fenglin. Beardsley's Art World [M]. Changsha: Hunan Fine Arts Publishing House, 1988

[7] British Beardsley. The Last Correspondence [M].Zhang Hengyi. Beijing:Xinxing Press, 2009

[8] Li Xingyuan. The Outline of Western Art History [M]. Changsha: Hunan Fine Arts Publishing House, 2002 